Original Research Article

\title{
A study of renal functions in asphyxiated term newborns
}

\author{
Saini $R^{1}$, Sehra $R N^{2}$, Verma $S^{3}$, Pansari $V_{K}^{4}$, Nagaraj $N^{5}$, Yadav $R^{6}$ \\ ${ }^{1}$ Dr. Saini R, Assistant Professor, Department of Pediatrics, ${ }^{2}$ Dr. Sehra RN, Professor, Department of Pediatrics, \\ ${ }^{3}$ Dr. Verma S, Professor, Department of Gynae and Obst, ${ }^{4}$ Dr. Pansari VK, Assistant Professor, Department of \\ Pediatrics, ${ }^{5}$ Dr. Nagaraj N, Senior Resident, Department of Pediatrics, ${ }^{6}$ Dr. Yadav R, Associate Professor, \\ Department of PSM. All authors are affiliated with Sawai Man Singh Medical College, Jaipur, Rajasthan, India \\ except Nagaraj $\mathrm{N}$ is affiliated with RML Hospital, Delhi, India.
}

Address for Correspondence: Dr R N Sehra, Professor, Department of Pediatrics, Sawai Man Singh Medical College, Jaipur, Rajasthan, India. Email - rnsehra@gmail.com

\begin{abstract}
Introduction: Hypoxia and ischemia can cause damage to almost every tissue and organ in the body. Birth asphyxia is the most important cause of renal damage in term infants. This study was performed to evaluate the renal functions and to compare them with various grades of birth asphyxia in term newborns. This was also compared with levels in healthy term newborns. Methods: The present study was conducted at the Special Care Neonatal Unit of Mahila Chikitsalaya, SMS Medical College, Jaipur. It was a hospital based comparative analysis conducted from October 2015 to September 2016. It included 100 consecutive term neonates who suffered asphyxia at birth as cases and 50 consecutive healthy term newborns as controls. Results: Out of 100 asphyxiated cases, 20\% had mild asphyxia (Apgar 6-7), 35\% had moderate asphyxia (Apgar 4-5) and 45\% had severe asphyxia (Apgar $\leq 3$ ). Oliguria (Transient and Persistent) was more commonly seen in severely asphyxiated babies as compared to mild asphyxia $(\mathrm{p}=0.014)$ and moderate asphyxia $(\mathrm{p}=0.006)$. Blood urea and serum creatinine levels on Day 2 and Day 3 of life were significantly raised in severely asphyxiated babies as compared to mildly asphyxiated newborn. The serum electrolytes showed no significant difference among the three categories of asphyxia. Conclusion: Early estimation of blood urea, serum creatinine and monitoring of urine output should be done in all asphyxiated newborns so that the renal dysfunction can be detected earlier and appropriate measures can be taken in time to prevent renal damage in such newborns.
\end{abstract}

Keywords: Asphyxia Neonatorum, Oliguria, Kidney Function Tests, Full Term, Newborns

\section{Introduction}

The frequency of perinatal asphyxia is approximately 1 to $1.5 \%$ of live births and inversely related to gestational age and birth weight [1]. Birth asphyxia is the most important cause of renal damage in term infants. The kidney is very sensitive to oxygen deprivation. Within $24 \mathrm{hrs}$ of an ischemic episode, renal insufficiency will occur. The condition is reversible, but prolonged renal insufficiency will cause increased damage leading to irreversible cortical or medullary necrosis [2]. Acute kidney failure (AKF) occurs in $3.4 \%$ to $24 \%$ of neonates admitted to neonatal intensive care units (NICUs). The kidneys of neonates are

Manuscript received: $20^{\text {th }}$ May 2017

Reviewed: $30^{\text {th }}$ May 2017

Author Corrected: $8^{\text {th }}$ June 2017

Accepted for Publication: $17^{\text {th }}$ June 2017 particularly susceptible to hypo perfusion because of the physiologic characteristics of neonatal kidneys, high renal vascular resistance, high plasma rennin activity, low glomerular filtration rate, decreased intercortical perfusion and decreased reabsorption of sodium in the proximal tubules [3]. Asphyxia can lead to multi organ dysfunction and a redistribution of cardiac output to maintain cerebral, cardiac, and adrenal perfusion while potentially compromising renal, gastrointestinal, and skin perfusion. Hypoxia and ischemia can cause damage to almost every tissue and organ in the body [4]. It is therefore not surprising that acute kidney injury (AKI) is common in asphyxiated neonates, occurring in up to $56 \%$ of these cases [5]. 
This study was performed to evaluate the renal functions and to compare them with various grades of birth asphyxia in term newborns. This was also compared with levels in healthy term newborns.

\section{Materials and methods}

The present study was conducted at the Special Care Neonatal Unit of Mahila Chikitsalaya, SMS Medical College, Jaipur. It was a hospital based comparative analysis conducted from October 2015 to September 2016. It included 100 consecutive term neonates who suffered asphyxia at birth as cases and 50 consecutive healthy term newborns as controls.

\section{Inclusion Criteria}

\section{Cases}

1. Term newborns with gestational age of 37 weeks or more.

2. Had asphyxia at birth (Apgar score of $\leq 7$ at 1 minute after birth and required resuscitation at birth) [7].

3. Clinical encephalopathy as assessed by neonatologist (manifestation of hypoxic ischemic encephalopathy (HIE) like altered tone, depressed level of consciousness, seizures).

\section{Controls}

1. Healthy term newborns who had completed 37 weeks or more.

2. No evidences of asphyxia at birth (Apgar score at 1 min after birth $>7$ ).

\section{Exclusion criteria}

1. Preterm infants (less than 37 weeks)

2. Severely dysmorphic infants with apparent lethal or major congenital malformations.

3. Prenatal exposure to medications that might be responsible for birth asphyxia.

4. Asphyxiated term newborns with septicemia.

5. Who did not give consent for study

Mothers of eligible newborns fulfilling inclusion criteria were explained about nature and purpose of the study and their informed written consent was taken to participate in the study. History about duration of gestational age and pregnancy related complications were taken. Thorough general and systemic examination including Apgar score, Ballard's score and neurological examination was done to reassure period of gestation and to assess degree of birth asphyxia [6].

Asphyxiated neonates were closely observed for abnormal neurologic signs suggesting hypoxicischemic encephalopathy (HIE) and development of complications. All neonates were observed for $72 \mathrm{hrs}$ after birth and morbidities particularly neurological were carefully recorded.

The cases were graded into HIE stages on the basis of neurological examination done on Day 2 and Day 3 of life [13]. All necessary investigations as indicated by clinical picture of the case were carried out in each baby. Besides the routine investigations, renal function tests (Blood urea, Serum Creatinine and Serum Electrolytes) were done for all cases and controls on Day 2 and Day 3 of life. The blood Investigations were performed as per standard methods in an identified laboratory. Permission from institutional research review board and ethical committee was taken prior to study.

Urine output was monitored by applying plastic collection bag (minicom) or by catheterization if required. Azotemia was defined as a blood urea concentration $>40 \mathrm{mg} \%$ and a serum creatinine concentration of $>1.2 \mathrm{mg} \%$ [7].

Oliguria was defined as a urine output of $<1$ $\mathrm{ml} / \mathrm{kg} / \mathrm{hr}$ and retrospectively was categorized as being "transient" if it was present in the first $24 \mathrm{hrs}$ of life only, "persistent" if it was present for the first $48 \mathrm{hrs}$ of life or more [7].

Statistical analysis- Linear variables were summarized as mean and standard deviation and were compared by using unpaired $\mathrm{T}$ test.

Categorically variables were expressed as proportions (\%) and were analyzed by using Fisher's exact test. Statistical software namely SPSS version 22.0 was used for all statistical calculations and Microsoft word and excel had been used to generate tables. A $\mathrm{P}$ value of $<0.05$ was considered significant. 


\section{Results}

Total 111 newborns were approved for the study. Out of them, 11 were excluded due to consent issues. There were no drop outs as end point of study was only after 72 hours. In the control group $60 \%$ were males and $40 \%$ females where as in asphyxiated babies $64 \%$ were males and $36 \%$ females. About $20 \%$ babies had a birth weight of less than $2500 \mathrm{~g}$, while in the cases it was $48 \%$. Babies with a birth weight between 2500 and $2999 \mathrm{~g}$ comprised $56 \%$ in the controls and $38 \%$ in the cases. Babies with a birth weight of $3000 \mathrm{~g}$ or more were $24 \%$ of the total in controls and $14 \%$ in the cases. Asphyxia was more common in babies with a birth weight less than 2500g. Out of 100 asphyxiated cases, 20\% had mild asphyxia (Apgar 6-7), 35\% had moderate asphyxia (Apgar $4-5)$ and $45 \%$ had severe asphyxia (Apgar $\leq 3)$. Male preponderance was seen in all grades of asphyxia.

Most of the babies under study were delivered by normal vaginal route (52\% controls and $47 \%$ cases) followed by lower segment cesarean section ( $44 \%$ controls and $35 \%$ cases) and others $18 \%$ (forcep, ventouse ). In the control group, $30 \%$ babies were born to primigravida mothers, $50 \%$ to second gravid and $20 \%$ to third gravid. Asphyxia was more commonly seen in primigravida mothers (46\%). The percentage of asphyxia decreased with increase in gravidity of mothers.

In the controls, $76 \%$ mothers received antenatal care as compared to $52 \%$ in the cases. Mothers who did not receive antenatal care comprised $24 \%$ of the total in controls as compared to $48 \%$ in the cases. Severe asphyxia was more common in babies of mothers who did not receive antenatal care. In the control group, the only adverse obstetrical factor observed was induction of labour in $12 \%$ babies. While in the cases, Fetal distress (35\%), Induction of labour (20\%), Pregnancy induced hypertension (15\%), Premature rupture of membranes (10\%) and Ante partum hemorrhage (6\%) were observed. Fetal distress (35\%) was the most common adverse obstetrical factor associated with birth asphyxia. Neurological manifestations like Hypotonia (68\%), Diminished reflexes (62\%), Seizures (56\%), Subtle Seizures (44\%), Irritability (30\%), Jitteriness (25\%) and Coma (7\%) were observed in the cases. Hypotonia, diminished reflexes and seizures were the most commonly observed neurological manifestations in asphyxiated babies. These were more pronounced in moderately and severely asphyxiated newborns.

All the controls had a normal urine output on Day 2 and Day 3 of life. While in the cases, $76 \%$ had oliguria (transient/persistent) and $24 \%$ had a normal urine output. Persistent oliguria was highest i.e. $24.44 \%$ in severe asphyxia followed by moderate and mild asphyxia (11.43\% and 5.00\% respectively). Statistically, urine output was found significantly associated with grade of asphyxia ("p'value $<0.05$ ). (Table-1)

Table-1: Oliguria versus grade of Asphyxia.

\begin{tabular}{|c|c|c|c|c|c|c|c|c|}
\hline \multirow{2}{*}{\begin{tabular}{c} 
Asphyxia \\
\cline { 2 - 9 }
\end{tabular}} & \multicolumn{2}{|c|}{$\begin{array}{c}\text { Normal Urine } \\
\text { Output }\end{array}$} & \multicolumn{2}{c|}{$\begin{array}{c}\text { Transient } \\
\text { Oliguria } \\
(<\mathbf{2 4} \text { hrs) }\end{array}$} & \multicolumn{2}{c|}{$\begin{array}{c}\text { Persistent } \\
\text { Oliguria } \\
(>\mathbf{4 8} \text { hrs) }\end{array}$} & \multicolumn{2}{c|}{ Total } \\
\cline { 2 - 9 } & No. & \% & No. & \% & No. & \% & No. & \% \\
\hline Mild (n=20) & 7 & 35.00 & 12 & 60.00 & 1 & 5.00 & 20 & 100.00 \\
\hline Moderate (n=35) & 13 & 37.14 & 18 & 51.43 & 4 & 11.43 & 35 & 100.00 \\
\hline Severe (n=45) & 4 & 8.89 & 30 & 66.67 & 11 & 24.44 & 45 & 100.00 \\
\hline Total & 24 & 24.00 & 60 & 60.00 & 16 & 16.00 & 100 & 100.00 \\
\hline
\end{tabular}

Chi-square $=12.546$ with 4 degrees of freedom; $P=0.014$

Above table shows that persistent oliguria was highest i.e. $24.44 \%$ in severe asphyxia followed by moderate and mild asphyxia (11.43\% and 5.00\% respectively). Blood Urea and serum creatinine levels were significant raised in cases as compared to controls on Day 2 and Day 3 of life. No significant difference was noted in the electrolytes. Raised blood urea levels on Day 2 and Day 3 of life were observed in $27 \%$ and $18 \%$ asphyxiated newborns respectively. Raised serum creatinine levels on Day 2 and Day 3 of life were observed in 25\% and $21 \%$ asphyxiated newborns respectively. (Table-2) 
Table-2: Biochemical Parameters on Day 2 in different grades of Asphyxia.

\begin{tabular}{|c|c|c|c|c|}
\hline Grades of & Parameter & Cases & Controls & P Value \\
\hline \multirow{4}{*}{ 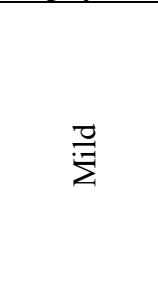 } & $\begin{array}{c}\text { Blood Urea } \\
(\mathrm{mg} \%)\end{array}$ & $28.30 \pm 2.02$ & $21.46 \pm 1.27$ & $0.005 * *$ \\
\hline & $\begin{array}{c}\text { Serum Creatinine } \\
(\mathrm{mg} \%)\end{array}$ & $0.87 \pm 0.08$ & $0.74 \pm 0.03$ & 0.054 \\
\hline & $\begin{array}{c}\text { Serum Sodium } \\
(\mathrm{mEq} / \mathrm{L})\end{array}$ & $134.51 \pm 1.63$ & $137.29 \pm 0.3$ & 0.483 \\
\hline & $\begin{array}{c}\text { Serum Potassium } \\
(\mathrm{mEq} / \mathrm{L})\end{array}$ & $4.85 \pm 0.15$ & $4.72 \pm 0.04$ & 0.684 \\
\hline \multirow{4}{*}{ 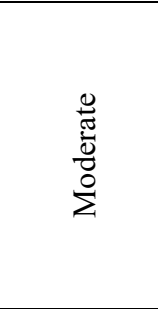 } & $\begin{array}{c}\text { Blood Urea } \\
(\mathrm{mg} \%)\end{array}$ & $38.31 \pm 3.39$ & $21.45 \pm 1.27$ & $<0.001 * *$ \\
\hline & $\begin{array}{l}\text { Serum Creatinine } \\
(\mathrm{mg} \%)\end{array}$ & $1.00 \pm 0.12$ & $0.74 \pm 0.03$ & 0.057 \\
\hline & $\begin{array}{l}\text { Serum Sodium } \\
(\mathrm{mEq} / \mathrm{L})\end{array}$ & $135.81 \pm 0.98$ & $137.29 \pm 0.31$ & 0.056 \\
\hline & $\begin{array}{c}\text { Serum Potassium } \\
(\mathrm{mEq} / \mathrm{L})\end{array}$ & $4.64 \pm 0.16$ & $4.72 \pm 0.04$ & 0.835 \\
\hline \multirow{4}{*}{$\begin{array}{l}0 \\
\stackrel{0}{0} \\
己 \\
\mathscr{D}\end{array}$} & $\begin{array}{c}\text { Blood Urea } \\
(\mathrm{mg} \%)\end{array}$ & $48.07 \pm 4.2$ & $21.46 \pm 1.27$ & $<0.001 * *$ \\
\hline & $\begin{array}{c}\text { Serum Creatinine } \\
(\mathrm{mg} \%)\end{array}$ & $1.31 \pm 0.15$ & $0.74 \pm 0.03$ & $0.001 * *$ \\
\hline & $\begin{array}{c}\text { Serum Sodium } \\
(\mathrm{mEq} / \mathrm{L})\end{array}$ & $136.25 \pm 0.75$ & $137.29 \pm 0.31$ & 0.102 \\
\hline & $\begin{array}{c}\text { Serum Potassium } \\
(\mathrm{mEq} / \mathrm{L})\end{array}$ & $4.56 \pm 0.13$ & $4.72 \pm 0.04$ & 0.222 \\
\hline
\end{tabular}

Above table shows that blood urea was significantly higher in mild, moderate and severe asphyxia where as serum creatinine was found significantly higher in severe birth asphyxia on day 2 of life.

Table-3: Biochemical Parameters on Day 3 in different grades of Asphyxia.

\begin{tabular}{|c|c|c|c|c|}
\hline Grades of Asphyxia & Parameter & Cases & Controls & P Value \\
\hline \multirow{4}{*}{$\stackrel{D}{\Sigma}$} & $\begin{array}{c}\text { Blood Urea } \\
(\mathrm{mg} \%)\end{array}$ & $31.45 \pm 1.34$ & $21.44 \pm 1.20$ & $<0.001 * *$ \\
\hline & $\begin{array}{c}\text { Serum Creatinine } \\
(\mathrm{mg} \%)\end{array}$ & $0.99 \pm 0.06$ & $0.65 \pm 0.03$ & $0.001 * *$ \\
\hline & $\begin{array}{l}\text { Serum Sodium } \\
(\mathrm{mEq} / \mathrm{L})\end{array}$ & $135.45 \pm 1.51$ & $136.78 \pm 0.04$ & 0.460 \\
\hline & $\begin{array}{c}\text { Serum Potassium } \\
(\mathrm{mEq} / \mathrm{L})\end{array}$ & $4.78 \pm 0.14$ & $4.65 \pm 0.06$ & 0.594 \\
\hline \multirow{4}{*}{ 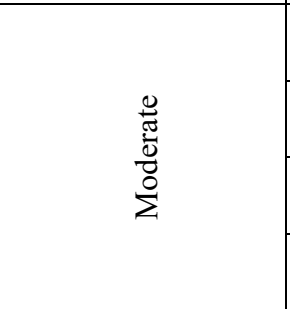 } & $\begin{array}{c}\text { Blood Urea } \\
(\mathrm{mg} \%)\end{array}$ & $41.66 \pm 4.49$ & $21.44 \pm 1.20$ & $<0.001 * *$ \\
\hline & $\begin{array}{c}\text { Serum Creatinine } \\
(\mathrm{mg} \%)\end{array}$ & $1.22 \pm 0.14$ & $0.65 \pm 0.03$ & $0.001 * *$ \\
\hline & $\begin{array}{l}\text { Serum Sodium } \\
(\mathrm{mEq} / \mathrm{L})\end{array}$ & $136.21 \pm 0.65$ & $136.78 \pm 0.04$ & 0.061 \\
\hline & $\begin{array}{l}\text { Serum Potassium } \\
(\mathrm{mEq} / \mathrm{L})\end{array}$ & $4.56 \pm 0.08$ & $4.65 \pm 0.06$ & 0.785 \\
\hline \multirow{4}{*}{$\begin{array}{l}0 \\
\stackrel{0}{0} \\
\stackrel{\Delta}{0}\end{array}$} & $\begin{array}{c}\text { Blood Urea } \\
(\mathrm{mg} \%)\end{array}$ & $54.80 \pm 6.35$ & $21.44 \pm 1.2$ & $<0.001 * *$ \\
\hline & $\begin{array}{c}\text { Serum Creatinine } \\
(\mathrm{mg} \%)\end{array}$ & $1.50 \pm 0.18$ & $0.65 \pm 0.03$ & $<0.001 * *$ \\
\hline & $\begin{array}{l}\text { Serum Sodium } \\
(\mathrm{mEq} / \mathrm{L})\end{array}$ & $135.60 \pm 0.65$ & $136.78 \pm 0.04$ & 0.103 \\
\hline & $\begin{array}{l}\text { Serum Potassium } \\
(\mathrm{mEq} / \mathrm{L})\end{array}$ & $4.60 \pm 0.07$ & $4.65 \pm 0.06$ & 0.595 \\
\hline
\end{tabular}


In mild and moderate asphyxiated babies, Blood urea (Day 2 and Day 3) and serum creatinine (Day 3) were significantly raised as compared to controls. Blood urea and serum creatinine levels on Day 2 and Day 3 of life were significantly raised in severely asphyxiated babies as compared to mildly asphyxiated newborn. No significant difference in these parameters was observed in between mild versus moderate asphyxia and moderate versus severe asphyxia. The serum electrolytes showed no significant difference among the three categories of asphyxia. (Table-3)

Above table shows that blood urea and serum creatinine both were significantly higher in cases of mild, moderate and severe asphyxia as compared to controls on day 3 of life.

\section{Discussion}

In the control group $60 \%$ were males and $40 \%$ females where as in asphyxiated babies $64 \%$ were males and $36 \%$ females. In an Indian study of 98 neonates of asphyxia also showed $66.3 \%$ were males and 33.7\% females [8]. Another studies also observed results similar to our study $[9,10]$. Higher incidence of asphyxia in males in our study can be explained on the basis of normal population pattern in this area.

Out of 100 asphyxiated cases, 20\% had mild asphyxia (Apgar 6-7), 35\% had moderate asphyxia (Apgar 4-5) and 45\% had severe asphyxia (Apgar $\leq 3$ ). Male preponderance was seen in all grades of asphyxia. A study showed mild (32.96\%), moderate (39.56\%) and severe cases (27.47\%) [11]. A study showed Apgar score at 5 minute was $>7$ in $33(46 \%)$, 4-6 in 37\% and Apgar $\leq 3$ in 10 (14\%) infants [9]. Asphyxia was more common in babies with a birth weight less than $2500 \mathrm{~g}$ (48\%). Other study also observed similar results in less than $2500 \mathrm{~g}$ newborns [12]. A western study done on 21 neonates of more than 37 weeks also reported (4.8\%) cases less than 2500g [13]. Our results differ from this study because the average weight of Indian baby is less than the western baby.

Most of the babies under study were delivered by normal vaginal route ( $52 \%$ controls and $47 \%$ cases) followed by lower segment cesarean section (44\% controls and 35\% cases) and others 18\% (forcep and ventouse) which were similar to an Indian study done on 86 cases of asphyxia [14]. In the control group, $30 \%$ babies were born to primigravida mothers, $50 \%$ to second gravid and $20 \%$ to third gravid. Asphyxia was more commonly seen in primigravida mothers (46\%), second gravid $28 \%$, third gravid $16 \%$ and multipara $10 \%$. The percentage of asphyxia decreased with increase in gravidity of mothers. Similarly another study also observed $44.2 \%$ primigravida mothers
[15]. In the present study mothers of $52 \%$ asphyxiated babies attended antenatal clinic. Out of 45 cases of severe birth asphyxia $60 \%$ were born to mothers who did not have antenatal check up. Lower antenatal visits as an important risk factor for asphyxia were also found in another Indian study on 86 cases of asphyxia [14].

In the present study all the controls had normal urine output on day 2 and day 3 of life while in cases $76 \%$ had transient/persistent oliguria and $24 \%$ had normal urine output. Transient oliguria was present in $60 \%$ and persistent in $16 \%$. Transient/persistent oliguria was more commonly seen in severely asphyxiated infants. A study reported $56 \%$ cases of oliguria, $44 \%$ of normal urine output, $38(53 \%)$ of transient oliguria and 3 (4\%) of persistent oliguria [9]. A study done by an Indian author showed non-oliguric (62.5\%) and oliguric $(37.5 \%)$ cases [16]. A study reported oliguria in $72 \%$ of cases because most of the cases were referred late [17].

Raised blood urea and serum creatinine levels on day 2 of life were observed in $27 \%$ and $25 \%$ and on day 3 in $18 \%$ and $21 \%$ cases respectively. Martin ancel A observed raised blood urea in 18 (25\%) and serum creatinine in $11(15 \%)$ cases on day 3 of life [9]. Perlman JM et al observed raised blood urea in $4(11 \%)$ and serum creatinine in $6(17 \%)$ [4]. In present study no alteration was observed in serum sodium and potassium on day 2 and day 3 of life in controls and cases. Similar findings were also observed in other studies $[10,16]$.

In present study raised blood urea and serum creatinine levels were observed more commonly in severely asphyxiated babies as compared to mild to moderated asphyxia. A western study done on 59 term babies of birth asphyxia also observed severe renal complications in cases who had severe 
asphyxia and metabolic acidosis [18]. In the present study, blood urea and serum creatinine levels were significantly raised in cases as compared to controls on day 2 and day 3 of life. No significant difference was noted in the electrolytes. Similar findings were also observed in other studies $[10,16]$.

\section{Conclusion}

Blood urea and serum creatinine levels on Day 2 and Day 3 of life were significantly raised in severely asphyxiated babies as compared to mild and moderate asphyxiated newborn. The serum electrolytes showed no significant difference among the three categories of asphyxia. Thus, we conclude that an early estimation of blood urea, serum creatinine and monitoring of urine output should be done in all asphyxiated newborns so that the renal dysfunction can be detected earlier and appropriate measures can be taken in time to prevent renal damage in such newborns.

\section{Abbreviations}

AKF - Acute kidney failure

NICU - Neonatal intensive care unit

AKI - Acute kidney injury

HIE - Hypoxic ischemic encephalopathy

Funding: Nil, Conflict of interest: None initiated, Perission from IRB: Yes

\section{References}

1. Anne R. Hansen, Janet S. Soul. Perinatal asphyxia and Hypoxic-Ischemic Encephalopathy. Chapter 55 in: John P. Cloherty, Eric C. Eichenwald, Ann R. Stark. Manual of Neonatal Care. $7^{\text {th }}$ Edition. New York: Lippincott, Williams and Wilkins; 2012, PP 711-28.

2. Dauber IM, Krauss AN, Symchych PS, Auld PA. Renal failure following perinatal anoxia. J Pediatr. 1976 May;88(5):851-55.

3. Mathur NB, Agarwal HS, Maria A. Acute renal failure in neonatal sepsis. Indian J Pediatr. 2006 Jun;73(6):499-02.

4. Perlman JM, Tack ED, Martin T, Shackelford G, Amon E. Acute systemic organ injury in term infants after asphyxia.Am J Dis Child.1989 May;143(5):617-20.doi:10.1001/archpedi.1989.02 150170119037.
5. Darkan AM, Alexender RT. Acute Kidney Injury post neonatal asphyxia. J Pediatr. 2011;158 (2 Suppl):e29-33.doi:10.1016/j.jpeds.2010. 11.010.

6. Ballard JL, Khoury JC, Wedig KL, Wang L, Eilers-Walsman BL, Lipp R . New Ballard Score, expanded to include extremely premature infants. J Pediatr.1991;119(3):417-23.

7. Friedlich PS, Evans JR, Tulassay T, Seri I. Acute and chronic renal failure. In Taeusch HW, Ballard RA, Gleason CA. Avery's diseases of the newborn. $8^{\text {th }}$ ed. Philadelphia: Elsevier Saunders; 2005. P. 1298-305.

8. Gupta BD, Sharma P, Bagla J, Parakh M, Soni JP. Renal failure in asphyxiated neonates. Indian Pediatr. 2005 Sep;42(9):928-34.

9. Martin-Ancel A, Garcia Alix A, Cabanas F, Burgueros M, Quero J. Multiple organ involvement in prenatal asphyxia. J Pediatr.1995;127(5):786-93.

10. Olavarría F, Krause S, Barranco L, Herrmann F, Paez V, Mezzano S, Leal N, López M. Renal function in full-term newborns following neonatal asphyxia. A prospective study. Clin Pediatr (Phila). 1987 Jul;26(7):334-38.

11. Ellis M, Manandhar N, Manandhar DS, Del Costello AM. An Apgar score of three or less at one minute is not diagnostic of birth asphyxia but is a useful screening test for neonatal encephalopathy. Indian Pediatr 1998;35(5): 415-21.

12. De Souza SW, Richards B. Neurological sequelae in newborn babies after perinatal asphyxia. Arch Dis Child. 1978 Jul;53(7):564-69.

13. Sarnat HB, Sarnat MS. Neonatal encephalopathy following fetal distress: A clinical and EEG study. Arch Neurol. 1976;33(10): 696-05.

14. Chandra S, Ramji S, Thirupuram S. Perinatal asphyxia: multivariate analysis of risk factors in hospital births. Indian Pediatr. 1997 Mar; 34 (3): 206-12.

15. Daga SR, Fernandes CJ, Soares M, Raote GK, Rao A. Clinical profile of severe birth asphyxia. Indian Pediatr. 1991;28(5): 485-88. 
16. Girish Gopal. Acute kidney injury in perinatal asphyxia.Indian J Pharma Biol res.2014;2(2):60-65.

17. Mortazav F, Sakha SH, Nejati N. Acute kidney Failure in Neonatal period. Iranian Journal of Kidney Disease. 2009;3(3):136-40.
18. Low JA, Panagiotopoulos C, Derrick EJ. Newborn complications after intrapartum asphyxia with metabolic acidosis in the term fetus. Am J Obstet Gynecol. 1994 Apr;170(4):1081-87.

\section{How to cite this article?}

Saini R, Sehra RN, Verma S, Pansari VK, Nagaraj N, Yadav R. A study of renal functions in asphyxiated term newborns. J PediatrRes.2017;4(06):363-369.doi:10.17511/ijpr.2017.i06.03. 